\title{
Hospital Waste Management Practices: A Case Study of Primary Health Care Centers, In Fagge Local Government Area, Kano State
}

\author{
A.B. Umar Rn, Rm, Rphn, Bnsc, M.Sc, Phd,Fwncn, Mohammed Nura Yahaya, Rn, \\ Bnsc. \\ Department Of Nursing Sciences, Faculty of Medicine, Ahamadu Bello University Zaria, Kaduna State, Nigeria.
}

\begin{abstract}
Hospital waste management constitutes special category of waste because they contain potentially harmful materials. The problems of how to manage hospital waste has become one of the critical concerns in Nigeria. A cross sectional descriptive study was carried out at Primary health care centers of Fagge local government, with the aim to examine the current practices and commitment to sustainable Hospital waste management practice. The study involved the evaluation of waste segregation, collection transportation, treatment, storage and final disposal. A 132 health professionals include; Nurses/Midwives public health nurses, community health workers \& paramedics are included. A self administered questionnaire was used as a tool for data collection to determine their waste management practices. An examination of the status of the waste management practices in phc facilities was carried out using the following criteria: Waste segregation, collection, treatment, transportation, storage and final disposal. The results shows that: Majority of waste segregation is $98.4 \%$ only sharps, waste collection $62.2 \%$ using bare hands, transportation $32.5 \%$ using wheel barrow within the hospital and $44.0 \%$ using carts by Yaro Boys for offsite transportation, waste storage and treatment $76.6 \%$ stored for 12 hourly, while treatment of infectious waste found to be $0.0 \%$, waste disposal $74.2 \%$ practiced land disposal method. This research revealed the pitfalls of hospital waste management in Phccs surveyed, and concluded by recommending a proper hospital waste management practices.
\end{abstract}

Key wards: Hospital waste, management, segregation, collection, treatment, disposal. Phc centers Fagge L.G.A.

\section{Introduction}

Hospital waste management has become a critical issue as it poses potential health risks and damage to the environment. It is an issue that is taking central place in the national health policies of many countries. In developing countries, hospital wastes have not received sufficient attention. This is because, very often, health issues compete with other sectors of the economy for the very limited resources available. Thus, management of hospital waste end up not getting the priority it deserves. In many countries, hazardous and medical wastes are still handled and disposed together with domestic wastes, posing a great health risk to municipal workers, the public and the environment. Hospital waste must be separated from municipal waste, but in many parts of Africa it tends to be collected along with the rest of the waste stream (Kgathi and Bolanee, 2001; Taru and Kuvarega, 2005). Most hazardous and toxic wastes are placed on landfills with few safeguards to protect nearby inhabitants and water sources from contamination. This is usually the case in developing nations (Hardoy, 1992). The WHO estimates that each year there are 8-16 million cases of hepatitis B Virus, 2.3-4.7 million cases of hepatitis C Virus and 80,000-160,000 cases of HIV due to unsafe injections and mostly due to very poor hospital waste management system (WHO,UNICEF,UNFPA, 1999). Unregulated clinical waste treatment and disposal has been linked to several public health threats. Solberg, (2009) reported that 240 people in Indian State of Gujarat contacted hepatitis B after receiving medical care with previously used syringes acquired through the illegal trade of clinical waste.The improper disposal of medical waste constitutes a problem in most of the developing countries. Recently, the Cape Town Municipality of South Africa gave a medical waste disposal company 24 hours to remove amputated body parts and foetuses that had been piling up outside its warehouse for some time (Barbeau, 2005).There have been numerous instances where medical wastes have been dumped in residential areas. The illegal dumping of medical wastes in disadvantaged residential areas has resulted in situations where children have been found playing with medical waste materials such as syringes. For example, the Tygerberg Hospital treated 48 children with AZT (Retrovir) after some were pricked with needles and others ate potentially lethal pills they found in a field in Elsie's River (Leonard, 2004).

Waste from medical facilities poses a risk to healthcare workers, patients and the local communities (Singh \& Prakash, 2007).

In developing countries like Nigeria, where many health concerns are competing for limited resources, it is not surprising that the management of healthcare wastes has received less attention and the priority it deserves. Unfortunately, practical information on this important aspect of healthcare management is inadequate and research on the public health implications of inadequate management of healthcare wastes are few and 
limited in scope. Although it is believed that several hundreds of tones of healthcare waste are deposited openly in waste dumps and surrounding environments, often alongside with nonhazardous solid waste. This problem has no geographical boundary it has cut across all the states and local governments in Nigeria.(Malumfashi, Mukhtar and Adamu, 2011).Therefore Kano state and Fagge local government are not an exception.

\section{Statement Of The Research Problem}

The essence of this research is that; there is a serious concern regarding hospital waste which has not been adequately managed especially in primary health care centers (PATHS, 2005). In most cases there is inadequate training of primary health care workers on hospital waste management practices and nonexistent segregation of hospital waste and risky disposal system. The dumping sites are open and uncontrolled and located in the midst of residential areas. In addition, the waste handling behavior of the people itself is risky. They dispose off their waste as cheaply and as quickly as possible without recourse to the hygienic means of doing it (Malumfashi, Mukhtar, \& Adamu, 2011). This motivated the researcher to carry out a research using Primary health centers (PHCC) in Fagge local Government Area of Kano State as the setting for the study.

\section{The main objectives of the study}

These include:

i. To identify how waste can be segregated into various components

ii. To find out how waste is collected and transported to waste disposal sites

iii. To discover the various methods of waste treatment and storage

iv. To learn about the various methods of final disposal of waste

\section{Research questions}

i. How is hospital waste segregated into various components?

ii. How is waste collected and transported to waste disposal sites?

iii. What are the existing procedures involved in treatment and storage of hospital waste in PHCs?

$\mathbf{v}$. What are the various methods of final hospital waste disposal?

\section{Significance of the study}

The importance of this study is to create the necessary awareness to the PHC staff of Fagge regarding the health risk of hospital waste. It will also recommend to Government And policy makers on the need to employ the necessary manpower and strategies on waste collection, storage, treatment and disposal, which will be beneficial to the community. And also to advise health providers on the need to ensure proper collection, storage, transportation, treatment and final disposal of hospital waste.

\section{Literature Review}

In developing countries, hospital waste is typically derived from two main sources: emergency relief donations (i.e. leftover from international donor response to either a humanitarian crisis or a natural disaster) and long-term healthcare services. The aim of healthcare services is to reduce health problems as well as prevent potential risk. As a result waste, which is potentially harmful to public health and the environment, are often generated. Leftover emergency relief donations normally create one of medical care waste issue, and can be dealt with in the same manner as longterm healthcare services management waste (Johannessen, Boyer,Hanrahan,Boyer,and Chandra,2000).

The World Health Organization defines hospital waste as the total waste stream from health care establishments, research facilities, laboratories, and emergency relief donations. (WHO, 1999).

A number of studies have indicated that the inappropriate handling and disposal of hospital waste poses health risks to health workers who may be directly exposed and to people near health facilities, particularly children and scavengers who may become exposed to infectious wastes and a higher risk of diseases like hepatitis and HIV/AIDS ( Adegbita ,Nwafor, Afon, Abegunde and Ba mise, 2010 ;Coker,2009;PATH,2009; WHO,1999,2002).

The World Health Organization estimates that each year there are about 8 to 16 million new cases of Hepatitis B virus (HBV), 2.3 to 4.7 million cases of Hepatitis C virus (HCV) and 80,000 to 160,000 cases of human immune deficiency virus (HIV) due to unsafe injections and mostly due to very poor waste management systems (WHO, 1999). A near total absence of institutional arrangements for HCW in Nigeria has been reported by others (Coker, Sangodoyin, Ogunlowo, 1998).

In effect, various methodologies have been used all over the world to assess and quantify Hospital waste. They include the use of physical observation, questionnaire administration and quantification (Adegbita et al., 2010; Olubukola, 2009; Phengxay et al., 2005), as well as checklists (Townend and 
Cheeseman, 2005) and private and public records (Coker et al., 2009). Recent studies in Nigeria has estimated waste generation of between 0.562 to $0.670 \mathrm{~kg} / \mathrm{bed} / \mathrm{day}$ (Longe and Williams, 2006) and as high as 1.68 $\mathrm{kg} / \mathrm{bed} /$ day (Olubunmi, 2009). A good example is given by the findings of the study in Lagos by (Olubukola, 2009) which reported the similarity in waste data and Hospital management practices in two General hospitals, characterized by a lack of waste minimization or waste reduction strategies, poor waste segregation practices, lack of instructive posters on waste segregation and disposal of hospital waste with general waste. And also a study carried out in Ibadan Nigeria reveals that there is a near total absence of institutional arrangement for hospital waste in Nigeria (Coker et al 2002). The mismanagement of hospital waste poses health risks to people and the environment by contaminating the air, soil and water resources. Hospitals and Primary health care centers are supposed to safeguard the health of the community. A study in Port Harcourt shows that only $1 \%$ of Primary Health Care Centers had a transport vehicle also $8 \%$ of PHCs had an established dumpsite (Stanley, et al 2011). More than $90 \%$ of the hospital waste generated in Nigeria is directly disposed on land in an unsatisfactory manner (Vivian, Blama, Ezemokwe, Okafor and Bawa, 2012).

Therefore, information on the amount of hospital waste and its management practices is rather nonexistent in spite of the hazards and epidemiological implications (UNDP, 2003).The Millennium development Goals (MDGs) also provide a good basis for the United Nations member States, of which Nigeria is one, to arouse public interest in environmental issues such as hazardous waste. Goal number seven urges member states to improve monitoring and compliance with environmental standards (Ngwuluka, Ochekpe, Odumosu and Sunday, 2009).

\section{Study setting and Design:}

\section{Methodology}

A cross sectional descriptive survey study was carried out in Primary Health Care Centers of Fagge local government Area Kano State Nigeria. Fagge L.G.A. is made up of 10 wards with a Population of 298,828 (National population Census, 2006). The specific Facilities of the study are Kwachiri Phcc, Rijiyar lemo Phcc, Jaba Phcc. The three Phc centers are the major health facilities in Fagge Local Government Area with about 132 staff, which includes; Nurses/Midwives, Chews,Chos, Pharmacy Technicians, Laboratory technologist and others. The people of Fagge are predominantly Hausa with Fulani, Kanuri,Yoruba Igbo,Igbira and Nupe as minority. The Occupation of majority of the populace is Tailoring and trading but wide variations of civil servants are present.

\section{Sample size and sampling procedure:}

The sampling technique used, is a non-probability sampling (census survey). According to statpac (2013); stated that sometimes, the entire population will be sufficiently small and the researcher can include the entire population in the study. This type of research is called census study because data is gathered on every member of the population. All professionals in 3 PHC centers constitute the sample size. The hospital includes; Rijiyar lemo PHCC with 53, Kwachiri PHCC 34, and Jaba 45 respectively making a total /target population of 132 , so the total population will be used for the study.

\section{Instrument for data Collection:}

Questionnaires were used. The questionnaires were in closed ended form in which questions have response categories concerning relevant to the topic of study and it was given to all the health workers in the 3 Health facilities. In all 132 responses were received and analyzed

\section{Ethical consideration}

i. Permission to conduct the study was obtained from the Department of Nursing sciences, Faculty of Medicine Ahmadu Bello University Zaria. A Letter of introduction was given by head of department and submitted to Primary health care department Fagge L.G.A. Kano state

ii. Ethical clearance to conduct the study was obtained from Ahmadu Bello University Teaching Hospital Science and Health Ethics Committee

iii. Informed consent was sought from all the staff involved in the study before proceeding with administering questionnaires.

iv. Confidentiality of respondents was ensured.

\section{Technique of data analysis:}

The data of this investigation were collected checked manually for completeness, errors, and subsequently inputted for analysis with a computer software programme called Statistical Package for Social Sciences 16.0 (SPSS). The discrete variables are expressed as percentages and frequency tables. The data are then presented on tables and charts after full analysis. 


\section{Results}

The majority of the participants showed that (18.2\%) were between 19-24 years of age, (25.0\%) $25-29$ years, $(22.0 \%)$ of $30-34$ years and (18.2\%) 35-39, (16.6\%) were 40 years and above. In their gender distribution the majority of the participants were Females (65.2\%) and (34.8\%) are males. By hospital setting distribution it showed that out of 132 participated (40.2\%) were from Rijiyar lemo phcc, while (34.0\%) from Jaba Phcc. Number of beds in the facility the majority of the facility has 20 beds $(75.0 \%)$ and $(2.2 \%)$ has 40 beds. The average number of outpatients per day is $(75.0 \%)$ as while as the number of average highest in patients per day is $(66.5 \%)$. By cadre distribution it showed that out of 132 participants $(100 \%), 81(61.4 \%)$ are community Health workers, Paramedics $41(31,8 \%)$ and the least are Nurses/Midwives with $8(6.8 \%)$ as showed on the analysis data of Table 1

The Hospital waste segregation in primary health care centers of Fagge local Government area.

The major findings of the study as shown in the analysis on data on table 2 revealed that $(98.4 \%)$ hospital survey segregate sharps waste, using safety box as medium of segregation as while as using empty fluid containers for segregation with (5.4\%). As such sharps waste is the major waste of PHCC.

Waste collection and transportation in Primary health care center majority of waste is collected daily by hospital attendants /cleaners and transported within the hospital premises $(62.2 \%)$ using bare hands with $(32.5 \%)$ using wheel barrow, and also off site waste transportation the study revealed that (49.3\%) used carts by yaro boys to transport waste off-site, infectious waste were not labelled by biohazard symbols as shown on table 3 in the data analysis.

Existing procedures involved in storage and treatment of hospital waste in primary health care center. This study revealed that majority of waste collected were stored in an open ground for 12 hours (76.6\%), none (0.0) of the hospital treat infectious waste before disposal as shown on table $\mathbf{4}$ of the data analysis, which highly risky to the hospitals staff, community and scavengers.

The waste disposal methods in primary health care centers. The majority of the hospital (74.2\%) practiced land disposal/ burning methods and (25.8\%) burying methods, all the hospital were not have incinerator as indicated on table $\mathbf{5}$ of data analysis.

Table1 Distribution of respondents according to their Socio-demographic characteristics $\mathbf{N}=132$

\begin{tabular}{|c|c|c|c|}
\hline & Age & FREQUENCY & PERCENTAGE (\%) \\
\hline & $19-24$ & 24 & 18.2 \\
\hline & 25-29 & 33 & 25.0 \\
\hline & 30-34 & 29 & 22.0 \\
\hline & 35-39 & 24 & 18.2 \\
\hline & 40 and above & 22 & 16.6 \\
\hline & Total & 132 & 100.0 \\
\hline \multirow[t]{4}{*}{$\mathbf{a}$} & Sex & & \\
\hline & Male & 46 & 34 \\
\hline & Female & 86 & 65.2 \\
\hline & Total & 132 & 100.0 \\
\hline \multirow[t]{5}{*}{ b } & Hospital name & & \\
\hline & Kwachiri phe & 34 & 25.8 \\
\hline & Rijiyar lemo phc & 53 & 40.2 \\
\hline & Jaba phc & 45 & 34.0 \\
\hline & Total & 132 & 100.0 \\
\hline \multicolumn{4}{|c|}{ c. Number of units in the hospital } \\
\hline & $1-2$ & 2 & 1.5 \\
\hline & $3-4$ & 5 & 3.8 \\
\hline & $5-6$ & 7 & 5.3 \\
\hline & 7-8 & 41 & 31.0 \\
\hline & 9 and above & 77 & 58.4 \\
\hline & Total & 132 & 100.0 \\
\hline \multirow[t]{7}{*}{ d } & Number of beds in the hospital & & \\
\hline & 10 & 17 & 12.9 \\
\hline & 20 & 98 & 74.3 \\
\hline & 30 & 14 & 10.6 \\
\hline & 40 & 3 & 2.2 \\
\hline & 50 above & $\mathbf{0}$ & 0.0 \\
\hline & Total & 132 & 100.0 \\
\hline \multirow[t]{6}{*}{ e. } & Average number of outpatients per day & & \\
\hline & $20-40$ & 99 & 75.0 \\
\hline & $50-70$ & 22 & 16.7 \\
\hline & 80-100 & 6 & 4.6 \\
\hline & $110-130$ & 5 & 3.7 \\
\hline & Total & 132 & 100.0 \\
\hline f. & Average number of inpatients per day & & \\
\hline
\end{tabular}




\begin{tabular}{|c|c|c|c|}
\hline & $10-20$ & 88 & 66.5 \\
\hline & $30-40$ & 42 & 32.0 \\
\hline & 50 and above & 2 & 1.5 \\
\hline & Total & 132 & 100.0 \\
\hline \multirow[t]{7}{*}{ g } & Profession & & \\
\hline & Doctor & $\mathbf{0}$ & 0.0 \\
\hline & Nurse/midwife & 9 & 6.0 \\
\hline & Community health workers & 81 & 61.4 \\
\hline & Public health nurse & $\mathbf{0}$ & 0.0 \\
\hline & paramedics & 42 & 31.8 \\
\hline & Total & 132 & 100.0 \\
\hline \multirow[t]{7}{*}{ h } & Years of experience & & \\
\hline & $1-5$ & 27 & 20.5 \\
\hline & $6-10$ & 49 & 37.1 \\
\hline & 11-15 & 21 & 15.9 \\
\hline & $16-20$ & 20 & 15.2 \\
\hline & 21 and above & 15 & 11.3 \\
\hline & Total & 132 & 100.0 \\
\hline
\end{tabular}

Table 2 Distribution of responses on waste segregation $N=132$

\begin{tabular}{|c|c|c|}
\hline Does your hospital segregate waste & Frequency & Percentage $(\%)$ \\
\hline Yes & 130 & 98.4 \\
\hline No & 2 & 1.8 \\
\hline Total & 132 & 100.0 \\
\hline \multicolumn{3}{|l|}{ a If yes into which categories } \\
\hline Infectious waste & $\mathbf{0}$ & 0.8 \\
\hline Pathological waste & $\mathbf{0}$ & 0.0 \\
\hline Sharps & 130 & 98.4 \\
\hline Chemical/pharmaceutical waste & $\mathbf{0}$ & 0.0 \\
\hline None of the above & 2 & 1.8 \\
\hline Total & 132 & 100.0 \\
\hline \multicolumn{3}{|l|}{ b How does your hospital segregate sharps } \\
\hline use of safety box & 125 & 94.6 \\
\hline puncture proof containers & $\mathbf{0}$ & 0.0 \\
\hline Plastic Bag & $\mathbf{0}$ & 0.0 \\
\hline empty fluid containers & 7 & 5.4 \\
\hline Total & 132 & 100.0 \\
\hline \multicolumn{3}{|l|}{ c Does your hospital colour code waste } \\
\hline Yes & $\mathbf{0}$ & 0.0 \\
\hline No & 132 & 100.0 \\
\hline Total & 132 & 100.0 \\
\hline \multicolumn{3}{|l|}{ d How does infectious waste segregated } \\
\hline use of plastic bags & $\mathbf{0}$ & 0.0 \\
\hline steel containers & $\mathbf{0}$ & 0.0 \\
\hline disinfectant containers & $\mathbf{0}$ & 0.0 \\
\hline all of the above & $\mathbf{0}$ & 0.0 \\
\hline none of the above & 132 & 0.0 \\
\hline Total & 132 & 100.0 \\
\hline
\end{tabular}

Table 3 Distribution of response on collection/transportation of waste $\mathrm{N}=132$

\begin{tabular}{|c|c|c|}
\hline How is waste collected and transported within the hospital & Frequency & Percentage (\%) \\
\hline using trolley & $\mathbf{0}$ & 0.0 \\
\hline using wheel barrow & 43 & 32.5 \\
\hline using cart & 7 & 5.3 \\
\hline using bare hands & 82 & 62.2 \\
\hline Total & 132 & 100.0 \\
\hline \multicolumn{3}{|l|}{ How is waste transported off-site } \\
\hline using carts & 65 & 49.3 \\
\hline using vehicles & 23 & 17.3 \\
\hline others & 44 & 33.4 \\
\hline Total & 132 & 100.0 \\
\hline \multicolumn{3}{|l|}{ Who transport the waste } \\
\hline hospital trained staff & $\mathbf{0}$ & $\mathbf{0 . 0}$ \\
\hline private company & $\mathbf{0}$ & 0.0 \\
\hline Government agency & 69 & 52.3 \\
\hline yaro boys & 58 & 44.0 \\
\hline others & 5 & 3.7 \\
\hline Total & 132 & 100.0 \\
\hline \multicolumn{3}{|l|}{ Does infectious waste labelled with the biohazards symbols } \\
\hline Yes & $\mathbf{0}$ & 0.0 \\
\hline No & 132 & 100.0 \\
\hline Total & 132 & 100.0 \\
\hline
\end{tabular}


Table 4 Distribution of responses on Hospital waste storage and treatment $\mathrm{N}=132$

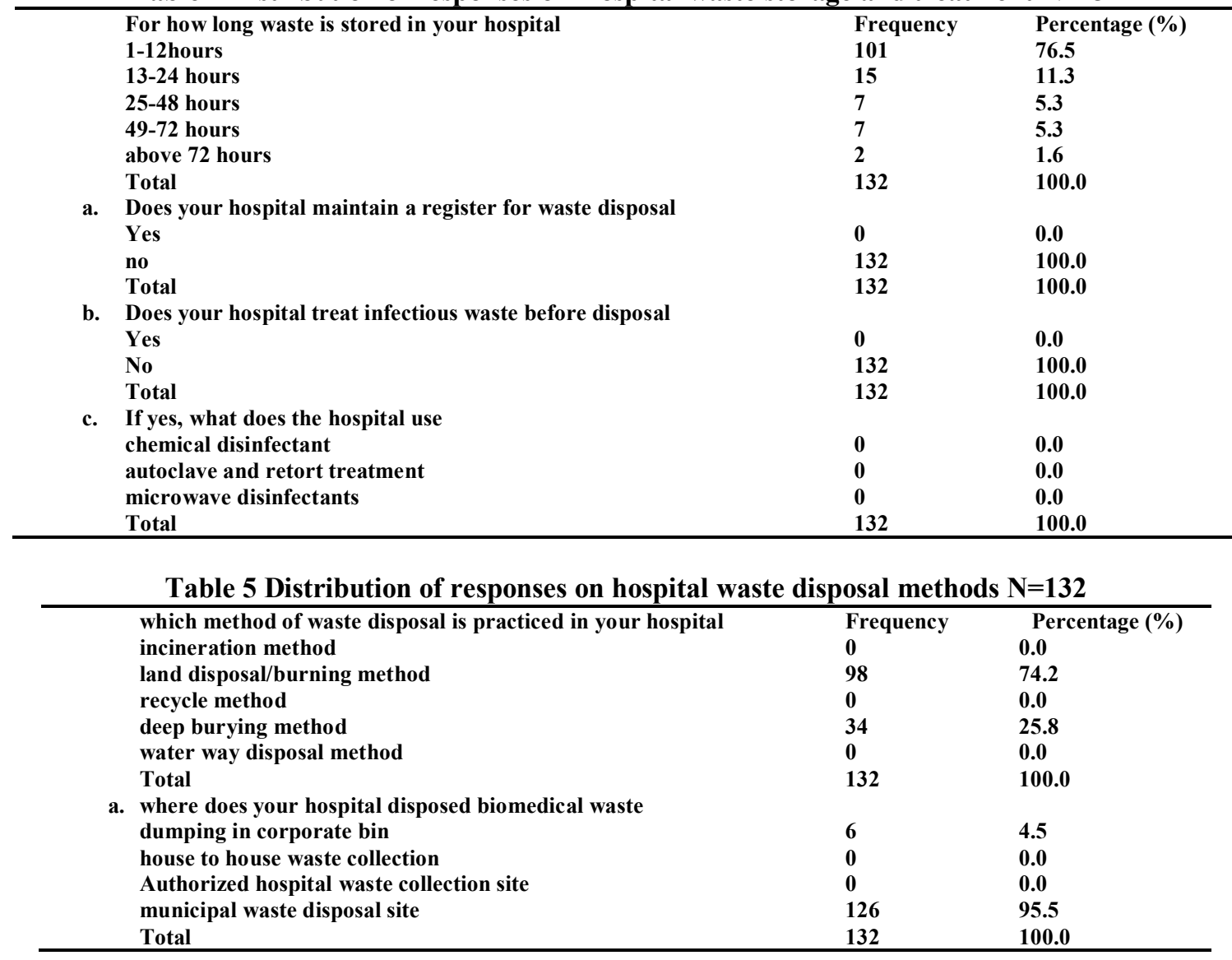

\section{Discussion Findings}

The findings shows indicates that majority of the respondents fell between the ages of 25 to 29 years with $(25.0 \%)$ from the distribution, Majority of the respondents were Females (65.2\%). Majority of the respondents were from rijiyar lemo phcc with $(40.2 \%)$ and $(58.4 \%)$ of the respondents were having 9 and above unit in their hospitals. Majority of the respondents (75.0\%) participate in the study were having 20 beds in their hospital. The average number of inpatient per day were $(66.5 \%)$, while highest average number of outpatient per day were $(66.5 \%)$. The majority of the respondents were community health workers $(61.4 \%)$ paramedics (31.8\%).The above findings illustrate those factors like sex, age, place of residents/work, profession, number of patients visits the hospital may influence the potential risk to health and the environment from improper handling of waste from hospital and clinics. The study is in line with various studies in the literature which indicated an association between factors such as sex, age, profession, work place, non chalance, deliberate negligence on part of the waste handlers (UNDP, 2003). Unfortunately, hospital waste management is not yet carried out with a satisfactory degree of safety by the staff in many parts of the globe especially in the underdeveloped world (Taru \& Kuranga, 2005).

Hospital waste segregation is an important step in reducing the volume of hazardous waste as its offers the ability to make accurate assessment of composition using labelled bags. Results from the research revealed that $(98.4 \%)$ of the hospital survey segregate only sharps using safety box. This is in congruence with the study conducted by (WHO, 1999; Acharya, 2000).

Majority of waste is collected daily by hospital attendant and cleaners transported within the hospital premises $(62.2 \%)$ mainly with the use of bare hands. Only $(32.5 \%)$ use wheel barrow to transport waste within the hospitals. which is contrary to the study of Johannessen, Dijkman, Bartone, Hanrahan, Boyer and Chandra (2000) This study reveals that majority of waste collected were stored in an open ground for 12 hours (76.6\%), 13-24 hours (11.3\%) before they are disposed off. This is not in congruence with a study carried out by Longe and Williams (2006). In an urbanized city of Lagos university teaching hospital (LUTH) and 2 maternity hospitals it was reported that waste moved three times daily to coincide with the shift changes by ground staff. These wastes were packed into a temporary storage area from where the waste transporter comes to collect it for disposal every morning. This variation could be explained by the fact that the wastes generated by the tertiary hospitals were greater than those obtained in this study, and also the availability of more staff in the tertiary hospitals. 


\section{Conclusions}

From the findings of this study, it can be concluded that Hospital waste must be separated from municipal waste, but in many part of Nigeria it tends to be collected along with the rest of the waste stream. Poor management of hospital waste has serious health implication to health workers, patients and the general public. Also, due to the toxic nature of hospital waste, improper handling may lead to the destruction of natural environment, lives and disturb the balance of the ecosystem. This study examined the hospital waste management practices in primary health care centers of Fagge L.G.A. Kano State, From the results of the study, it is observed that medical waste management is not practiced according to WHO's recommended standards. There are some areas where hospital wastes are not properly managed. It is imperative for significant investment in the proper management of hospital waste in order to reduce the health risk it poses. The researcher hopes that this study will create the awareness regarding the problem of hospital waste management in primary health care centers and will generate interest for systematic control efforts for effective hospital waste management.

\section{Recommendations}

In view of the above observations, the recommendations were made based on the findings of the study. With hope of improving the management of hospital waste in primary health care centers of Fagge local government.

1. The PHC department of Fagge local government area should train all the staff on management and proper waste handling within the hospitals using WHO guide lines manual.

2. There is need for proper segregation of infectious and non-infectious hospital waste. And the provision of plastic bags and strong plastic containers for infectious waste, the containers for infectious waste should be marked with Biohazard symbol.

3. The Hospital waste should be carried in a special purpose vehicle or in a special leak-proof, lidded container for in and outside waste disposal services.

4. The hospital should develop clear plans and policies for proper management and disposal of hospital wastes. Incinerators should be provided for all the primary health care centers

\section{References}

[1]. Akter N. (2011).Medical waste management: a review, International Journal of science and pharmaceutical educational research.1 (1);53-61

[2]. Al-khatib IA,Ali-Shyayeh MS, A-Qaroot YS. (2005) Management of health care waste in circumstances of limited resources: a case study in Hospital of Nabalu city,Palastine. Waste management researchRetrieved 13-052013. P27 (3):305-312

[3]. Bartlett J.E.11, Kotrilik J.w, Haggings (2001) Organizational research; Determining appropriate sample size for survey research performance Journal;19 (1) 43-50

[4]. Bassey BE, Ben-Coker MO, Aluyi HS(2006).Characterization and management of solid medicalwastein Federal capital Territory, Abuja Nigeria. Journal of African Health Sciences 6;6(1): 65-67

[5]. Coker AO, Sangodoyin AY,Ogunlowo OO (2008). Managing hospital waste in Nigeria proceedings; proceedings of the 24 ${ }^{\text {th }}$ WEDC conference ,Islamabad,Pakistan;70-72.

[6]. Diaz LF, Savage GM, Eggerth LL. (2005). Alternatives for the treatment and disposal of health care wastes in developing countries. Journal of waste management; $25 ; 626-637$

[7]. Health care without harm (2013).www.noharm.org; 35-36.Retrieved 16-05-2013.

[8]. Longe EO,Williams AA.(2012). A Preliminary study of medical waste managent in Lagos metropolis, Nigeria. Iran journal of environmental health science; 3 (2):133-139.

[9]. Mahmood SS, Malik R, Azim W. (2003) A Study of waste generation, collection and disposal in a tertiary hospital in Pakistan. Journal of medical research; 24(4):13-17

[10]. Ngwuluka N,Ochekpe N,Odumosu P. Sunday (2012) A. waste management in health care establishment within Jos metropolis, Nigeria. African Journal of environmental science and technology: 3(12); 459-465

[11]. Ogbonna DN. (2011) Characteristics and waste management practices of medical waste in health care institution in portharcout,Nigeria. Journal of soil science and environmental management. 2 (5):132-141

[12]. Patil GV, Pokhrel K. (2006) Biomedical solid waste management in an Indian hospital: A case study, Journal of waste managementOnline, 25 (3):592-599 Retrieved15-05- 2013 on http//www.ncbi.nml.nih.gov/pubmed.

[13]. Rutala W, sarubbi F. (2001) Management of Infectious waste from Hospitals, Journal on Infectious waste management; 4 (4):198203

[14]. Sarkar SKA, Haque MA, Khan TA. (2012) Hospital waste management in Sylhet city. journal of Engineering and applied science; 1 (2):32-41.Retrieved 15-05-2013 http://www.arpnjournals.com

[15]. Sawalem M, Selic E Herbell JD. (2010) Hospital waste management in Libya : A case study. Journal of waste management ; 29:1370-1375.Retrieved 15-05-2013 http:/www.elsevier.com/locate/wasman.

[16]. Singh S.Prakash V. (2007) Toxic environmental releases from medical waste incineration: A review of environmental monitoring; 132:67-31. Retrieved 15-05-2013. http://www.ncbi.nlm.nih.gov/pubmed.

[17]. Sobotova L, Noscova T, Volekova A, Aghol G. (2006), practical training on nasocomial infection in a hospital environment, indoor build environ;15(1):73-76.

[18]. Solberg KE (2009). Trade in Medical waste causes deaths in India. The lancet onlineRetrieved16-05$2013 \mathrm{http} / \mathrm{www}$. thelancet/journals/lancet/articles/11;140-6736(09)60632-2

[19]. Stanley HO,Okpara KE,Chukwujekwu DC,Agbozu IE,Nyenke CU.(2011) Healthcare waste management in port Harcourt Metropolis, American Journal of scientific and industrial research;2(5):767-773. 
[20]. Statpac Survey sampling methods of small population; Copyright C (2013) StatPac Inc., All Rights http://www.statpac.com 12-04-2013

[21]. Taru P.Kuvaraga Aj. (2005) Solid waste management: The case of Palirenjatwa hospital Zimbababwew, Revbiomedical journal ; p16:157-158

[22]. Tudor TL,Townend WK, Cheeseman CR, Edgarv JE.(2009) An overview of Arising and large scale treatment technologies for healthcare waste in the united Kingdom. The Journal of the international solid wastes and public cleansing association; 27 (4):374

[23]. World Health Organization, (2001) Review of health impacts from microbiological hazards in Health care wastes WHO Geneva draft: $22-46$

[24]. World Health Organization. Health care waste management (2011): Health care and its safe management.

[25]. World Health Organization. Wastes from health care activities (2007). WHO fact sheet No. 253, Reviewed. 